\title{
Effect of dietary phosphorus level and supplemental phytase on performance of Hisex Brown laying hens and egg shell quality
}

\author{
Barbara Z. Kamińska ${ }^{1}$, Bogumiła Skraba ${ }^{1}$ and J. Koreleski ${ }^{2}$
}

\author{
Research Institute of Animal Production \\ ${ }^{I}$ Department of Feed Science and Animal Products \\ ${ }^{2}$ Department of Animal Nutrition \\ 32-083 Balice, Poland
}

(Received 26 March 1996; accepted 9 July 1996)

\begin{abstract}
The experiment was carried out on Hisex Brown hens aged 26-48 wecks divided into 12 groups of 18 birds kept in single cages. Layers were fed wheat-maize-soyabean meal diets containing $0.50,0.55$ and $0.60 \%$ total phosphorus (TP), $0.25,0.30$ and $0.35 \%$ available phosphorus (AP) supplemented with $0,150,300$ or 450 units of microbial phytase (FTU) per kg. Hens were fed diet containing $0.50 \%$ TP supplemented with 300 FTU showed the highest laying rate $(93 \%)$ and good egg shell quality. However, the thickest egg shells and the highest breaking strenght were found when diets containing $0.30-0.35 \% \Lambda \mathrm{P}$ were supplemented with $150 \mathrm{FTU}$. Hens fed diet with $0.25 \%$ AP $+300 \mathrm{FTU}$ excreted $100 \mathrm{mg} /$ day $/$ hen less $\mathrm{P}$ than those fed diet with $0.35 \% \mathrm{AP}(0.60 \% \mathrm{IP})$, not supplemented with phytase. As the optimal levels in the diet are considered $0.25 \% \mathrm{AP}+300 \mathrm{FTU}$ or $0.30 \% \mathrm{AP}$ +150 FTU.
\end{abstract}

KEY WORDS: layers, phosphorus, phytase

\section{INTRODUCTION}

The results of studies published in recent years (e.g. Belyavin, 1991; Nys, 1995; Rao et al., 1996) point to considerable differences with respect to content of total phosphorus (TP) or available phosphorus (AP) in the diets of layers, and its effect on performance and egg shell quality. The published values for AP range from 0.28 to $0.53 \%$ and for TP from 0.57 to $0.70 \%$. 
On the other hand, the current trend is to reduce the content of phosphorus fed to animals, including poultry, in order to limit its excretion to the environment. The amount of TP excreted can be reduced either by the choice of components of diets or by increased its utilization through the addition of a phytase-containing enzyme preparation to the diet.

The aim of this study was determine the optimal level of phosphorus in diets, with or without phytase, as well as the minimum addition of phytase to feed mixtures used in practice in the feeding of high performance iayers.

\section{MATERIAL AND METHODS}

The experiment was carried out with 216 Hisex Brown hens aged 26-48 weeks, divided into 12 groups of 18 birds kept individually in cages. The hens were fed ad libitum diets (Table 1 ) containing $0.5,0.55$ or $0.6 \%$ total phosphorus (TP) what corresponded to $0.25,0.30$ and $0.35 \%$ available phosphorus (AP). Each of the three diets was fed unsupplemented (control) or supplemented with 150,300 or 450 units of phytase (FTU) in preparation Natuphos ${ }^{\mathrm{D}} 5000$. Utilization of $\mathrm{P}$ by the birds was determined on 6 hens of each group on the 32nd week of life. Feed intake and excreta voided were recorded during five days.

Individual egg production was estimated daily and the weight of the eggs was determined once a month on five conseculive days, at 30th, 38th and 46th week of life from 12 layers of each group. A total of 432 eggs were examined. The weight

TABELA 1

Composition of mixtures

\begin{tabular}{lccc}
\hline Ingredients & 1 & 2 & 3 \\
\hline Ground wheat & 42.7 & 42.4 & 42.1 \\
Ground maize & 20 & 20 & 20 \\
Soyabean oilmeal, 42\% & 16 & 16 & 16 \\
Wheat bran & 10 & 10 & 10 \\
Meat meal, 55\% & 3 & 3 & 3 \\
Limestone & 7.5 & 7.5 & 7.5 \\
Dicalcium phosphate & - & 0.3 & 0.3 \\
Na-Cl & 0.3 & 0.3 & 0.3 \\
Vitamin-mineral premix DJ & 0.5 & 0.5 & 0.5 \\
ME kcal/kg, calculated & 2601 & 2595 & 2590 \\
& & & \\
Analyscd, \% & 17.07 & 16.89 & 16.76 \\
$\quad$ crude protein & 3.05 & 3.19 & 3.27 \\
Ca & 0.53 & 0.57 & 0.62 \\
total P & 0.30 & 0.30 & 0.30 \\
phytic P & & & \\
\hline
\end{tabular}


of the egg, specific gravity, breaking strength on the long axis, weight of yolk, white and dry shell as well as their proportion in the weight of the whole egg, shell thickness at three points and its density were measured.

Total phosphorus was determined colorimetrically according to Fiske and Subbarow (1925), phytin phosphorus as described by Antoniewicz et al. (1992).

Statistical evaluation of the results was by analysis of variance using SAS method in two systems: a. two-factors: three levels of phosphorus and 4 levels of phytase and $\mathrm{b}$. one-factor for 12 groups.

\section{RESULTS}

The initial body weight of the hens was $1.82 \mathrm{~kg}$ and final $2.06 \mathrm{~kg}$. Daily feed intake was from 110 to $140 \mathrm{~g}$, and averaged $128 \mathrm{~g}$. Feed intake was the highest in hens of the control group, when the feed mixtures were not supplemented with phytase $(131.7 \mathrm{~g})$, and the lowest $(125.2 \mathrm{~g})$ when the diets contained $300 \mathrm{FTU}$.

The flock was healthy, with low mortality, unrelated to the experimental factors.

\section{Laying rate}

Hisex Brown hens not receiving addition of phosphorus in their feed (mixure 1) laid less eggs $(P \leqslant 0.05)$ with thinner shells $(P \leqslant 0.01)$. The addition to the feed containing $0.50 \% \mathrm{TP}(0.25 \% \mathrm{AP})$ of $300 \mathrm{FTU} / \mathrm{kg}$ resulted in increased laying rate from 85.5 to $93.3 \%$, corresponding to 15 eggs per layer. Besides the mentioned group, high performance (average $92 \%$ ) was found for hens receiving in their feed: $0.25 \% \mathrm{AP}+450 \mathrm{FTU} ; 0.30 \% \mathrm{AP}+450 \mathrm{FTU}$ or $0.35 \% \mathrm{AP}+150$ FTU/kg (Table 2).

\section{Eggs weight}

The heaviest eggs (61.4-61.6) were laid by hens fed mixture 1 with lowest phosphorus content $(0.25$ and $0.30 \% \mathrm{AP}$, without phytase, and $0.25 \% \mathrm{AP}+450$ FTU). The average weight of eggs from hens fed mixture 3 , containing $0.35 \%$ AP was significantly lower $(59.5 \mathrm{~g})$ than from hens receiving mixtures 1 and 2 $(60.6 \mathrm{~g})$. The smallest eggs $(59.1 \mathrm{~g})$ were laid by hens receiving $0.35 \% \mathrm{AP}+450$ FTU (Table 2).

\section{Egg content}

The proportion of yolk in the eggs averaged $26.6 \%$ in all groups throughout the experiment. The level of $P$ in the diets and supplemental phytase did not affect the proportion of white and yolk in the eggs. 
TABLE 2

Effect of dietary phosphorus (P) level and phytase supplement on performance of laying hens

\begin{tabular}{lccccccc}
\hline Dietary P level \% & \multicolumn{7}{c}{ Phylase supplement FTU/kg diet } \\
P total (P available) & 0 & 150 & 300 & 450 & Mean & SEM & P x FTL \\
\hline Laying rate, & & & & & & & $\vdots$ \\
$0.50(0.25)$ & $85.5^{\mathrm{c}}$ & $90.8^{\mathrm{ab}}$ & $93.3^{\mathrm{a}}$ & $91.7^{\mathrm{ab}}$ & $09.5^{\mathrm{a}}$ & 0.81 & \\
$0.55(0.30)$ & $89.4^{\text {ab }}$ & $90.8^{\mathrm{ab}}$ & $87.9^{\mathrm{ac}}$ & $92.0^{\mathrm{ab}}$ & $90.0^{\mathrm{a}}$ & 0.75 & \\
$0.60(0.35)$ & $91.2^{\mathrm{ab}}$ & $92.6^{\mathrm{ab}}$ & $91.2^{\mathrm{ab}}$ & $90.1^{\mathrm{abc}}$ & $90.8^{\mathrm{a}}$ & 0.93 & \\
Mean & $89.2^{\mathrm{a}}$ & $91.4^{\mathrm{a}}$ & $90.8^{\mathrm{a}}$ & $91.3^{\mathrm{abc}}$ & 90.4 & 0.48 & $\mathrm{x}$ \\
SEM \pm & 1.10 & 0.77 & 1.04 & 0.85 & & & \\
Egg weight, g & & & & & & & \\
$0.50(0.25)$ & 61.6 & 59.8 & 59.7 & 61.5 & $60.6^{\mathrm{a}}$ & 0.41 & \\
$0.55(0.30)$ & 61.4 & 60.4 & 60.2 & 60.6 & $60.6^{\mathrm{a}}$ & 0.36 & 0 \\
$0.60(0.35)$ & 59.4 & 59.5 & 60.0 & 59.1 & $59.5^{\mathrm{b}}$ & 0.50 & \\
Mean & $60.8^{\mathrm{a}}$ & $59.9^{\mathrm{b}}$ & $60.0^{\mathrm{ab}}$ & $60.4^{\mathrm{ab}}$ & 60.3 & 0.25 & NS \\
SEM \pm & 0.51 & 0.47 & 0.56 & 0.42 & & & \\
Egg mass, kg & & & & & & & \\
$0.50(0.25)$ & 8.17 & 8.31 & 8.54 & 8.66 & 8.43 & 0.08 & \\
$0.55(0.30)$ & 8.40 & 8.38 & 8.07 & 8.52 & 8.34 & 0.07 & \\
$0.60(0.35)$ & 8.29 & 8.38 & 8.37 & 8.13 & 8.29 & 0.10 & \\
Mean & 8.30 & 8.36 & 8.33 & 8.44 & 8.35 & 0.05 & NS \\
SFM \pm & 0.07 & 0.08 & 0.07 & 0.09 & & & \\
\hline
\end{tabular}

$a, b-P \leqslant 0.05$

NS - not signilicant

\section{Egg shell quality}

Eggs with the thickest shell $(0.381-0.386 \mathrm{~mm})$, high breaking strength $(4.06-4.19 \mathrm{~kg})$, high specific gravity $\left(1.092 \mathrm{mg} / \mathrm{cm}^{3}\right)$ and high density $(84.4-84.9$ $\left.\mathrm{mg} / \mathrm{cm}^{2}\right)$ were laid by hens feed mixtures with $0.30 \%$ AP supplemented with 150 or $450 \mathrm{FTU}$ or $35 \% \mathrm{AP}+150 \mathrm{FTU} / \mathrm{kg}$. The quality of the egg shell from hens fed a diet containing $0.25 \% \mathrm{AP}$, supplemented with 150 or $300 \mathrm{FTU} / \mathrm{kg}$ was also good (Table 3).

The largest number of broken and cracked eggs $(8.0-10.4 \%)$ was laid by hens fed diets without phytase or with the mixture containing $0.50 \%$ TP supplemented with 150 FTU. The addition of 300 FTU to the mixture 1 reduced the number of cracked eggs to $1.6 \%$, whereas the addition of $150 \mathrm{FTU}$ to the mixtures containing 0.55 to $0.60 \%$ TP reduced the number of cracked eggs to $3.1-3.3 \%$.

\section{Phosphorus balance}

The amount of phosporus intakc was calculated on the basis of chemical analysis which were slightly higher than tabular data (Table 1). 
TABLE 3

Egg specific gravity $\left(\mathrm{g} / \mathrm{cm}^{3}\right)$, breaking strength $(\mathrm{kg})$, shell thickness $(\mu \mathrm{m})$, shell density $\left(\mathrm{mg} / \mathrm{cm}^{2}\right)$ and shell percent

\begin{tabular}{|c|c|c|c|c|c|c|}
\hline \multirow{2}{*}{$\begin{array}{l}\text { Dietary } \mathrm{P}, \% \\
\mathrm{P} \text { total (P available) }\end{array}$} & \multicolumn{6}{|c|}{ Phylase supplement FTU/kg diel } \\
\hline & 0 & 150 & 300 & 450 & Mean & P $\times$ FTU \\
\hline \multicolumn{7}{|l|}{ Spccific gravity } \\
\hline $0.50(0.25)$ & 1.085 & 1.091 & 1.089 & 1.038 & $1.088^{\mathrm{B}}$ & \\
\hline $0.55(0.30)$ & 1.090 & 1.092 & 1.089 & 1.092 & $1.091^{\mathrm{A}}$ & \\
\hline $0.60(0.35)$ & 1.039 & 1.0921 & 1.091 & 1.090 & $1.090^{\mathrm{A}}$ & \\
\hline Mcan & $1.088^{\mathrm{B}}$ & $1.091^{\mathrm{A}}$ & 1.090 & $1.090^{\wedge \mathrm{B}}$ & $1.090^{\mathrm{AB}}$ & NS \\
\hline \multicolumn{7}{|l|}{ Breaking strength } \\
\hline $0.50(0.25)$ & 3.69 & 3.93 & 4.01 & 3.81 & $3.86^{\mathrm{b}}$ & \\
\hline $0.55(0.30)$ & 4.04 & 4.06 & 4.09 & 4.10 & $4.07^{\mathrm{a}}$ & \\
\hline $0.60(0.35)$ & 3.75 & 4.19 & 4.02 & 4.10 & $4.01^{\mathrm{ab}}$ & \\
\hline Mcan & $3.82^{\mathrm{b}}$ & $4.06^{\mathrm{a}}$ & $4.04^{a}$ & $4.00^{\mathrm{nb}}$ & 3.98 & NS \\
\hline \multicolumn{7}{|l|}{ Shell thickness } \\
\hline $0.50(0.25)$ & 347 & 374 & 369 & 366 & $364^{\mathrm{B}}$ & \\
\hline $0.55(0.30)$ & 366 & 381 & 369 & 386 & $375^{\mathrm{A}}$ & \\
\hline $0.60(0.35)$ & 368 & 384 & 378 & 373 & $376^{\Lambda}$ & \\
\hline Mean & $361^{\mathrm{B}}$ & $379^{\mathrm{A}}$ & $372^{\mathrm{A}}$ & $375^{\mathrm{A}}$ & 372 & NS \\
\hline \multicolumn{7}{|l|}{ Shell density } \\
\hline $0.50(0.25)$ & $77.3^{\mathrm{B}}$ & $82.5^{\wedge}$ & $82.0^{\mathrm{A}}$ & $81.2^{\mathrm{AB}}$ & $80.7^{\mathrm{B}}$ & \\
\hline $0.55(0.30)$ & $82.0^{\wedge}$ & $84.4^{\wedge}$ & $80.8^{A B}$ & $84.9^{n}$ & $83.0^{\wedge}$ & \\
\hline $0.60(0.35)$ & $81.6^{\mathrm{AB}}$ & $84.9^{\Lambda}$ & $83.0^{4}$ & $81.6^{\mathrm{AB}}$ & $82.8^{\mathrm{All}}$ & $\mathrm{x}$ \\
\hline Mean & $80.3^{b}$ & $83.9^{\mathrm{A}}$ & $81.9^{\mathrm{AB}}$ & $82.5^{\mathrm{AB}}$ & 82.2 & \\
\hline \multicolumn{7}{|l|}{ Shell percent } \\
\hline $0.50(0.25)$ & 9.15 & 9.83 & 9.71 & 9.65 & $9.58^{8}$ & \\
\hline $0.50(0.30)$ & 9.76 & 10.05 & 9.67 & 10.10 & $9.89^{\mathrm{A}}$ & \\
\hline $0.60(0.35)$ & 9.71 & 10.13 & 9.95 & 9.81 & $9.89^{\mathrm{A}}$ & \\
\hline Mean & $9.54^{\mathrm{R}}$ & $10.00^{\mathrm{A}}$ & $9.78^{\mathrm{AR}}$ & $9.85^{A}$ & 9.79 & $N S$ \\
\hline
\end{tabular}

a, b-P $\leqslant 0.05 ; \mathrm{A}, \mathrm{B}-\mathrm{P} \leqslant 0.01$

NS - not significant

When the $\mathrm{P}$ intake increased from 674 to $857 \mathrm{mg} /$ day/hen the $\mathrm{P}$ excreted rose from 134 to $233 \mathrm{mg} /$ day/hen, i.e. the $\mathrm{P}$ retained increased from 20 to $27 \%$ (Table 4). The addition of 300 FTU to the mixture containing $0.50 \%$ TP resulted in an increase of retained phosphorus from 134 to $186 \mathrm{mg} /$ day/hen. The addition of 300 FTU to a diet containing $0.55 \%$ TP resulted in increase of $\mathrm{P}$ retained from 186 to $217 \mathrm{mg}$. The supplementation the mixture containing $0.60 \%$ TP of phytase did not cause further increase of $P$ retention. 
TABELA 4

Phosphorus balance

\begin{tabular}{|c|c|c|c|c|c|c|}
\hline \multirow{2}{*}{$\begin{array}{l}\text { Total P } \\
\text { in feed } \\
\text { PT }(\%)\end{array}$} & \multirow{2}{*}{$\begin{array}{c}\text { Phytase } \\
\text { supplement } \\
\text { FTU } / \mathrm{kg}\end{array}$} & \multicolumn{4}{|c|}{$\mathrm{P} \mathrm{mg} / \mathrm{day} / \mathrm{hen}$} & \multirow{2}{*}{$\begin{array}{c}\mathrm{P} \\
\text { in eggs* }\end{array}$} \\
\hline & & intake & output & retained & $\begin{array}{c}\text { egg weight } \\
\text { day/hen }\end{array}$ & \\
\hline \multirow{4}{*}{0.50} & 0 & 674 & 540 & 134 & 51.7 & 115.8 \\
\hline & 150 & 639 & 502 & 137 & 49.5 & 110.8 \\
\hline & 300 & 708 & 522 & 186 & 61.8 & 138.4 \\
\hline & 450 & 719 & 543 & 176 & 57.6 & 129.0 \\
\hline \multirow{4}{*}{0.55} & 0 & 824 & 638 & 186 & 60.6 & 135.7 \\
\hline & 150 & 769 & 564 & 205 & 57.3 & 128.3 \\
\hline & 300 & 745 & 528 & 217 & 51.8 & 116.0 \\
\hline & 450 & 749 & 519 & 230 & 56.7 & 127.0 \\
\hline \multirow{4}{*}{0.60} & 0 & 857 & 624 & 233 & 54.2 & 121.4 \\
\hline & 150 & 845 & 612 & 612 & 54.7 & 122.5 \\
\hline & 300 & 775 & 583 & 192 & 49.4 & 110.6 \\
\hline & 450 & 822 & 567 & 225 & 53.0 & 118.7 \\
\hline
\end{tabular}

* for calculation $130 \mathrm{mg} \mathbf{P} / \mathrm{egg}$ of $58 \mathrm{~g}$ weight was taken as a standard

\section{DISCUSSION}

Optimum amount of phosphorus in diet not supplemented with phytase

The feed mixture used in the experiment, employed in practical conditions, contained a small amount of feed of animal origin : meat meal containing $24 \mathrm{~g}$ of $\mathrm{P}$. This mixture, not supplemented with phosphorus, contained $0.50 \% \mathrm{TP}$ $(0.25 \% \mathrm{AP})$. On this feed the laying rate of hens averaged $85.5 \%$ over a period of 5 months. Similar results were obtained earlier in an experiment on Hisex White hens (Kamińska et al., 1994).

The amount of $\mathrm{P}$ in this diet, used in our experiment, was probably insufficient to obtain maximal laying rate according to genetic potential of Hisex Brown hens. This is confirmed by the results obtained for group of layers receiving $0.60 \%$ TP $(0.35 \%$ AP) whose laying rate during the same period was $91.2 \%$.

In the experiment of Usayran and Balnave (1995) the laying rate of New Hampshire $\mathrm{x}$ White Leghorn hens fed a mixture containing wheat, sorgo, soyabean meal and soya oil with $0.12 \%$ AP was $85.9 \%$. An increase in phosphorus content did not cause any increase in the laying rate. The hens probably were not genetically predisposed to lay more eggs and their requircment for phosphorus was low. Similarly in studies by Rodriguez et al. (1984) hens fed maize-soyabean mixtures containing $0.15 \%$ AP laid fewer eggs (laying rate $74 \%$ ) than hens receiving $0.30-0.40 \% \mathrm{AP}$, whose laying rate was $76-79 \%$. 
Similar results of laying rate $(81.3 \%)$ were obtained by Summers et al. (1976) when hens were fed a diet containing $0.35 \% \mathrm{AP}$; the level of phosphorus from 0.15 to $0.55 \%$ did not significantly affect the weight of the eggs. Daghir et al. (1985) feeding hens a maize-soyabean diet also found that at $0.15 \%$ AP the laying rate was significantly lower $(73.4 \%)$ than in the groups receiving $0.25,0.35$ or $0.45 \%$ AP $(76.5 \%)$. The level of phosphorus did not influence the weight of the eggs $(60.6 \mathrm{~g})$ in this experiment but the shells were thinner when the hens were fed a diet containing $0.45 \%$ AP. Similar results have been presented by El Boushy (1979); laying rate was low $(52.9 \%)$ when AP content was $0.16 \%$ and the largest number of eggs was obtained from hens fed a diet containing between 0.20 and $0.40 \%$ AP. The egg shell quality was the best when a diet with low AP content $(0.16 \%)$ was used and the heaviest eggs $(62.2 \mathrm{~g})$ were at $1.0 \% \mathrm{AP}$, what its in conflict with our results. According to Miles et al. (1983) the use of a diet containing less than $0.30 \% \mathrm{TP}$ resulted in reduced feed intake and lowered laying rate of hens. Also Owings et al. (1977) found reduced egg shell thickness when maize-soyabean diet not supplemented with feed of animal origin or phosnhorus, containing $0.30 \% \mathrm{TP}(0.10 \% \mathrm{AP})$ was fed. When the diet was supplemented with $0.18 \%$ inorganic phosphorus to reach the values of $0.48 \%$ TP $(0.28 \%$ AP) the laying rate increased to $85.5 \%$ and the egg shells also became thicker. These results have been confirmed by Rao et al. (1995) who showed that the use of a diet containing less than $0.23 \%$ AP negatively affects the laying rate.

The results of the studies mentioned above indicate that the best results are obtained with $0.35 \%$ available phosphorus in the diet. In our experiments, in which the mixture containing $42 \%$ wheat and $10 \%$ wheat bran was used, the best laying rate (Table 2) and best egg shell quality (Table 3) were obtained for hens fed a diet containing $0.55 \% \mathrm{TP}$, corresponding to $0.30 \% \mathrm{AP}$.

\section{Optimal level of phytase}

Most studies on the use of phytase in feed mixtures for hens were carried out with broilers but relatively few experiments were made with layers. Peter (1992) points to a significant improvement in laying rate and feed intake when phylase of microbial origin was added to a maize-soyabean diet containing $0.12 \%$ of nonphytin phosphorus but does not give the amount of phytase used. Similarly, Simmons et al. (1992) found that the addition of $200 \mathrm{U}$ of microbial phytase was sufficient. Nys (1995), after Sauveur (1989), mentions that for a diet containing 300 units of plant origin phytase the amount of mineral phosphorus added to the diet can be reduced to $0.12 \%$. Similar results were obtained by Usayran and Balnave (1995) who found that when a diet containing over $40 \%$ wheat and 200 $\mathrm{U}$ of plant origin phytase was used no insufficiency of phosphorus was observed even at $0.12 \% \mathrm{AP}$ in the diet. In the experiments of these authors the addition of 
$500 \mathrm{U}$ of microbial phytase to a diet containing 0.32 or $0.46 \%$ TP $(0.12$ or $0.24 \%$ AP, respectively) has a negative effect on laying rate and egg shell quality from hens consuming 125-128 g of feed with laying rate below $80 \%$. In our experiments hens taking up approx. $128 \mathrm{~g}$ of mixture increased their laying rate from 85.5 to $90.8 \%$ as a result of the addition of $150 \mathrm{FTU}$ to a diet containing $0.50 \%$ TP $(0.25 \%$ AP), not supplemented with phosphorus. The supplementation the feed mixture of 300 FTU resulted in maximum laying rate $(93.3 \%)$ but a further increase of phytase to 450 FTU did not enhanced the laying rate.

Taking, after Cromwell and Coffrey (1993) and Usayran and Balnaven (1995), the content of plant phytase in wheat as $300 \mathrm{U}$, in bran $700 \mathrm{U}$ and in soyabean meal $150 \mathrm{U}$, its content in the diets used in our experiment was 220 FTU $/ \mathrm{kg}$ feed. This amount was, however, insufficient for highly productive layers. Only when $300 \mathrm{FTU}$ were added to the diet the maximum laying rate was obtained by hens fed a diet containing 3\% meat meal, without additional phosphate, containing $0.50 \% \mathrm{TP}(0.25 \% \mathrm{AP})$. Maximum thickness of the shells $(381-0.386 \mathrm{~mm})$, greatest breaking strength $(4.06-4.19 \mathrm{~kg})$ and greatest specific gravity of the eggs $\left(1.092 \mathrm{~g} / \mathrm{cm}^{3}\right)$ were obtained with a diet containing 0.55 and $0.60 \%$ TP $(0.30$ and $0.35 \% \mathrm{AP})$, supplemented with 150 FTU or feed mixture containing $0.55 \%$ TP $(0.30 \%$ AP) supplemented with 450 FTU.

The amount of added phytase of microbial origin should be adjusted to the content of available phosphorus in the diet and amount of phytase of plant origin, as well as to the production potential of the birds and amount of phosphorus needed for egg production.

\section{Phosphorus balance}

The studies of many authors (e.g. Owing et al.,1977; Roland and Farner, 1982; Miles et al., 1983), have shown that the intake of relatively small amounts of $P$ (approx. $300-400 \mathrm{mg} /$ day) by the hens enables satisfactory laying rate. However, basing on the results of many experiments, Roland (1986) considers that the intake of $P$ by hens should be higher, reaching about $700 \mathrm{mg} / \mathrm{hen} / \mathrm{day}$ at the peak of laying and between 500 and $600 \mathrm{mg}$ later on. This assumption seems to confirm the results obtained by Keshavarz (1986) who found that, depending on $P$ intake from the diet $(540-880 \mathrm{mg})$, the utilization of $\mathbf{P}$ ranged from 21.1 to $30.5 \%$. According to Usayran and Balnave (1995), with daily intake of $P$ between 352 and $837 \mathrm{mg}$, the utilization of this element ranged from 19 to $29 \%$ and was therefore similar to that observed by Keshavarz (1986).

In our experiment the intake of phosphorus by hens receiving the feed mixture not supplemented with phosphorus $(0.50 \% \mathrm{TP})$ was $650 \mathrm{mg}$ per day, and in the group with highest level of phosphorus in the diet $-857 \mathrm{mg} /$ day. 
The content of phosphorus in an egg, adopted as an average of $130 \mathrm{mg}$, was as high as the average daily phosphorus retention by hens in the deficiency group $(134 \mathrm{mg}$ ). The addition of 150 FTU to feed containing $0.50 \%$ TP did not affect phosphorus retention, whereas the addition of $300 \mathrm{FTU}$ increased its retention to $186 \mathrm{mg} /$ day, that is to the same amount as with $0.55 \%$ TP in the feed. The retention of phosphorus was the highest in hens fed a diet containing $0.55 \% \mathrm{TP}$ $+450 \mathrm{FTU}$ and $0.60 \% \mathrm{TP}$ with or without $150 \mathrm{FTU}$. In the case of a diet containing $0.60 \% \mathrm{TP}$, the addition of 300 or $450 \mathrm{FTU}$ did not have any effect on the phosphorus retention. The supplementation of the mixture, without feed phosphate, with 300 FTU reduced the excretion of phosphorus by 100 $\mathrm{mg} /$ day/bird compared to the amount excreted by layers receiving $0.60 \% \mathrm{TP}$ $(0.35 \% \Lambda \mathrm{P})$. These data are compatible with the results of $\mathrm{K}$ lis et al. (1991) who indicates the reduction of $\mathrm{P}$ excretion by $42 \mathrm{mg} / \mathrm{day} / \mathrm{hen}$ after the addition of 500 FTU to the feed containing $0.30 \%$ TP $(0.25 \%$ phytin $\mathrm{P})$.

\section{REFERENCES}

Antillon A., 1976. PhD Thesis, Cornell University, New York (ac. to Hopkins et al., 1989) Antoniewicz A., Dumańska K., Ombach A., 1992. Availability of phosphorus from field bean (Vicia $f a b a$ ) and lupin (Lupinus albus) seeds to broiler chickens. J. Anim. Feed Sci. 1, 127-137

Belyavin C.G., 1991. Feed composition and egg-shell quality. In: Proceedings of 8 th European Symposium on Poultry Nutrition, WPSA, Venezia-Mestre (Italy), pp. 117-133

Cook F., Briggs G.M., 1990. The nutritive value of eggs. In: W.J. Stadelman, O.J.Cotterill (Editors). Egg Science and Technology. Food Products Press, New York, pp. 141-163

Cromwell G.L., Coffey R.D., 1993. An as feed ingredients for non-ruminant.Proceedings of Maryland Nutrition Conference for Feed Manufactures, pp. 146-158 (ac. to Usayran and Balnave, 1995)

Daghir N.J., Farran M.T., Kaysi S.A.,1985. Phosphorus requirement of laying hens in a semiarid continental climate. Poultry Sci. 64, 1382-1384

El Boushy A.R., 1979. Available phosphorus in poultry. I. Effect of phosphorus levcls on the performance of laying hens and egg quality. Neth. J. Agric. Sci. 27, 176-183

Fiske C.H., Subbarow Y., 1925. The colorimetric determination of phosphorus. J. Biol. Chem. 66, $375-400$

Forst T.J., Roland D.A.Sr., 1991. The influence of various calcium and phosphorus levels on tibia strength and cgg-shell quality of pullets during peak production. Poultry Sci. 70, 963-969

Hopkins J.R., Ballantyne A.J., Jones J.L.O., 1989. Dictary phosphorus for laying hens. In: D.J.A. Cole, W. Haresign (Editors). Recent Developments in Poultry Nutrition. Butterworths, London, Boston, Sydncy, pp. 231-238

Kamińska B.Z., Skraba B., 1992. Changes in cgg shell quality during the first year of laying in hens. J. Anim. Feed Sci. 1, 51-58 
Kamińska B.Z., Skraba H., Koreleski J., 1994. Effect of dietary phosphorus levels and phytase supplement on performance of laying hens and egg shell quality. In: Proceedings of 9th European Poultry Conference, Glasgow (Scotland), Vol. 1, pp. 383-384

Keshavarz K., 1986. The effect of dietary levels of calcium and phosphorus on performance and retention of these nutrients by laying hens. Poultry Sci. 65, 114-121

Klis F.W. van der, Versteegh H.A.J., 1991. (ac. to Schöner F.J.: Review of the biological effects and the economical importance of phytase in broilers and layers. In: From Research and Practical Experience, Edition 30, Use of Natuphos ${ }^{\circledR}$ in pigs and poultry. Presentation at the 4th BASF Animal Nutrition Forum, 1992)

Miles R.D., Costa P.T., Harms R.H., 1983. The influence of dietary phosphorus level on laying hen performance, egg-shell quality and various blood parameters. Poultry Sci. 62, 1033-1037

Nys Y., 1995. Influence of nutritional factors on egg shell quality at high environmental temperature. In: R.C. Briz (Editor). Proceedings of the 6th European Symposium on the Quality of Eggs and Egg Products, Zaragoza (Spain), pp. 209-220

Owings W.J., Sell J.L., Balloun S.L., 1977. Dietary phosphorus needs of laying hens. Poultry Sci. 56, 2056-2060

Peter W., 1992. Investigation on the use of phytase in feeding of laying hens. Proceedings of 19 th World's Poultry Congress, Arnsterdanm, Vol. 3, p. 672

Rao S.K., Roland D.A.Sr., Orban J.I., Rabon H.W.Jr., Bryant M.M., 1995. Age at sexual maturity influences the response of Single Comb White Lcghorn pullets to marginal and low levels of dietary phosphorus. J. Nutr. 125, 1342-1350

Rodriguez M., Owings W.J., Sell J.I.,.1984. Influence of phase feeding available phosphorus on egg production characteristics, carcass phosphorus content and serum inorganic phosphorus levels of three layers strains. Poultry Sci. 63, 1553-1562

Roland D.A.Sr., 1986. Egg shell quality III. Calcium and phosphorus requirement of commercial Leghorns. World's Poultry Sci. J. 42, 154-165

Roland D.A. Sr., Farmer M., 1982. Studies concerning possible mechanism for the varying response of different phosphorus levels on egg shell quality. Poultry Sci. 61, 1393 (Abstr.)

Simons P.C.M., Jongblocd A.W., Vcrstecgh H.A.J., Kemme P.A., 1992. Improvement of phosphorus availability by microbial phytase in poultry and pigs. Proceedings of Georgia Nutrition Conference for Feed Industry, pp. 100-109 (ac. to Usayran and Balnave, 1995)

Summers J.D., Grandhi R., Leeson S., 1976. Calcium and phosphorus requirements of the laying hen. Poultry Sci. 55, 402-413

Szczerbińska D., 1995. Egg-shell quality, hatchability and their relations to the origin of the flocks (in Polish). PhD.Thesis, Agriculture University of S7crecin

Usayran N., Balnave D., 1995. Phosphorus requirements of laying hens fed on wheat-based diets. Brit. Poultry Sci. 36, 285-301

Yannakopoulos A.L., Morris T.R., 1979. Effect of light, vilamin D and dietary phosphorus on eggshell quality late in the pullet laying year. Brit. Poultry Sci. 20, 337-342

Ziolecka A., Kużdowicz M., 1993. Table of the mineral content in feedstuffs (in Polish). In: The Kielanowski Institute of Animal Physiology and Nutrition (Editor). Nutrient requirement of poultry. Nutritive value of feeds. $2^{\text {nd }}$ ed., Jabłonna, pp. 79-83 


\section{STRESZCZENIE}

Wpływ poziomu fosforu i dodatku fitazy do mieszanek na wyniki produkcyjne kur nieśnych Hisex Brown oraz jakość skorupy jaj

Doświadezenie wykonano na kurach Hisex Brązowy, od 26 do 48 tygodnia życia, podzielonych na 12 grup po 18 ptakow, trzymanych w indywidualnych klatkach pr $\%$ miesięcy. Kury żywiono mieszankami pszenno-kukurydziano-sojowymi zawierającymi $0,50,0,55$ i $0,60 \% \mathrm{P}$ ogólnego (TP), $(0,25,0,30 \mathrm{i} 0,35 \% \mathrm{P}$ przyswajalnego - AP) uzupetnionymi o $0,150,300$ lub 450 jednostek fitazy na $\mathrm{kg}$ (FTU $/ \mathrm{kg}$ ). Kury otrzymujące w paszy $0,50 \%$ TP $(0,25 \%$ P), nie zawierająccj fosforanu paszowego. lecz. uzupełnionej 300 FTU uzyskały najwyżşą nieśnośc (93\%) przy dobrej jakości skorup jaj. Najgrubsze skorupy, o najwiçkszẹj wytrzymałości na zgniatanic, uzyskano przy skarmianiu paszy zawierającej $0,55-0,60$ TP $(0,30-0,35 \%$ AP) uzupetnionej 150 FTU. Nioski خywione mieszanką zawierająca 0,50 TP $(0,25 \%$ AP) +300 FTU wydalały o $100 \mathrm{mg} /$ dobę/kurę mniej fosforu niż otrzymujące paszę zawierają $0.60 \mathrm{TP}(0,35 \mathrm{AP})$, nie uzupelnioną fitazą. Za optymalną można u/nać paszę zawierającą $0.55 \mathrm{TP}(0,25 \% \mathrm{AP})+300 \mathrm{FTU} / \mathrm{kg}$ lub $0.55 \mathrm{TP}(0,30 \% \mathrm{TP})+150 \mathrm{FTU} / \mathrm{kg}$. 